Int. J. Electrochem. Sci., 15 (2020) 3729 - 3739

\title{
Simple Fabrication of Reduced Graphene Oxide - Ionic Liquid Composite Modified Electrode for Sensitive Detection of Sulfadiazine
}

\author{
Jing-Ying Ma ${ }^{1}$, Xiao-Ping Hong ${ }^{2}$ * \\ ${ }^{1}$ Department of Construction, Zhejiang College of Construction, Hangzhou 311231, China \\ ${ }^{2}$ Department of Chemistry, Zhejiang Sci-Tech University, Hangzhou 310028, China \\ *E-mail: xpnghong@ sina.com
}

doi; 10.20964/2020.05.76

Received: 6 January 2020 / Accepted: 5 February 2020 / Published: 10 April 2020

\begin{abstract}
A convenient amperometric sensor based on incorporation of the reduced graphene oxide (rGO) and $\mathrm{N}$ octyl-pyridinium-hexafluorophosphate $\left(\mathrm{OPPF}_{6}\right)$ ionic liquid (IL) as the selective receptor was described. The synergistic cooperation of the $\mathrm{rGO}$ and $\mathrm{OPPF}_{6}$ contributed to a perfect performance of the electrochemical sensor. Compared with a bare glassy carbon electrode (GCE), the composite of rGO$\mathrm{OPPF}_{6}$ greatly improved the performance for the detection of sulfadiazine (SD) including a low anodic potential, sensitive current response, and good selectivity. The trace residues of the SD could be linearly assessed in the concentration range of $0.22-63.00 \mu \mathrm{mol} / \mathrm{L}(\mu \mathrm{M})$ with a detection limit of $0.07 \mu \mathrm{M}$. Additionally, the prepared sensor was successfully applied for the detection of the SD in an animal feed with recovery higher than $90 \%$. The results agreed well with those obtained by high-performance liquid chromatography.
\end{abstract}

Keywords: sulfadiazine, graphene, ionic liquid, food safety, sensor

\section{$\underline{\text { FULL TEXT }}$}

(C) 2020 The Authors. Published by ESG (www.electrochemsci.org). This article is an open access article distributed under the terms and conditions of the Creative Commons Attribution license (http://creativecommons.org/licenses/by/4.0/). 